\title{
THE ROLE OF HUMAN CAPITAL IN THE COMPETITIVE PLATFORM OF SOUTH AFRICAN INDUSTRIES
}

\author{
EPJ KLEYNHANS \\ School of Economics, Risk Management \& International Trade \\ North West University \\ eknepjk@puk.ac.za
}

\begin{abstract}
The objective of this study was to investigate the role of human capital in the competitive platform of South African industries and to determine the ability of their human capital to address the challenges of modern technology and globalisation. Attention is given to the competitive strengths and investment opportunities, including the quality and availability of human resources, labour cost, level of education and skills, vocational and industry related training facility, work ethics, productivity, workplace regulations, as well as efficiency of the civil service; including productivity and competitiveness indexes. The study found that the level of human capital in South African industries is much higher than the general perception and not the worst element of South Africa's competitive platform. The findings also indicated challenges, like absentees due to AIDS and other factors, a shortage of artisans and proficiency towards modern technology and innovation, which limits competitiveness.
\end{abstract}

Key words

Labour productivity, Human Capital, competitiveness, production factor

The role of human capital in the competitive platform of South African manufacturing industries is investigated in this paper. International competition is intensifying following international trade agreements, like GATT, and the effect of modern technology and globalisation, while tariffs and trade restrictions are declining. This exposes companies to international price and cost structures, which can replace local sales and with it local employment that manufacture those commodities. On the other hand productive human capital can provide a country with a competitive edge that could lead to economic growth and enhance everyone's welfare.

Human resources are an important factor of production and have a direct impact on the competitiveness of firms. Human capital is those elements in humans that enhance the quality of labour, such as skills, knowledge and wisdom, which make it worth more in the production process. Improvement in the quality of human resources can lead to lower unit costs of production and sales and in that way decreases marginal cost structures, enabling firms to trade products at lower prices and better quality. A supply of quality labour in a country can then lead to competitive markets and growth.

This paper commence with a theoretical discussion on the role of human capital in the competitiveness of firms and the country, followed by a review of the available literature of the subject. Then the empirical results of a survey conducted among South African manufacturers will be described.

\section{Human capital as a factor of production}

In Economics, natural resources, capital goods, labour and entrepreneurship are considered to be the four factors utilised as inputs in the production process. Half off these: labour, management and/or entrepreneurship consist of people. Their knowledge, skills and ability to produce, present human capital to the production process. The higher the stock of human capital the more output can be delivered per labour unit and the higher its value to the process. Labour is therefore an important factor in a country's industrial competitiveness platform.

Competitiveness relate to a firm's ability to enlarge its market share. A firm can conquer a growing share of market demand by selling more goods and services. This will be possible when the firm can supply at lower prices or better quality, reliable supply, low risk, providing a superior total sales package and a better image. In all of these aspects human capital has a role to play.
Improving labour productivity enhances competitiveness. Although some studies on price competitiveness ignore labour altogether (e.g. Siggle, 2001), others like Mazumdar and Van Seventer (2004) estimate price competitiveness solely considering labour. Productivity is calculated as the total production per production factor input. $\left(\mathrm{TP} / \mathrm{Pf}_{\mathrm{in}}\right)$. Labour productivity is then determined as the average product, which is the output per labour unit $\left(\mathrm{AP}_{\mathrm{L}}=\right.$ $\mathrm{TP} / \mathrm{L}$ ). The more output per labour unit the more valuable labour becomes.

Optimal resource allocation is found at the point where the marginal productivity delivered by a factor of production per last Rand spent are equal in all factor markets. Thus $\mathrm{MP}_{\mathrm{L}} / \mathrm{w}=$ $\mathrm{MP}_{\mathrm{C}} / \mathrm{i}$, where MP are the marginal products of Labour and capital, respectively, $\mathrm{w}$ is the wage rate and $\mathrm{i}$ the price of capital (usually interest rates). When the additional product $\left(\mathrm{MP}_{\mathrm{L}}\right)$ yield by labour increases without increase in price, the quality of labour is improving and its worth increases $\left(\mathrm{MP}_{\mathrm{L}} / \mathrm{L} \uparrow\right)$. In this way labour makes the production process more competitive. This might shift the total production function up to a higher level, which Sollow saw as a prerequisite for sustainable economic growth and development (Todaro \& Smith, 2004, p. 130). This also makes labour more valuable than other production factors. Capital will be substituted for labour, creating more employment in the economy, enhancing everyone's wealth.

When human capital becomes more valuable per unit of production it implies that a firm's cost functions is depressed. Average and total variable costs shift down and the marginal cost curve moves to the right. These down and rightward shifts of the cost functions imply higher productivity and a better competitive position.

As marginal cost curves represents the supply curve of firms, added together to form the market supply curve, higher labour productivity implies an outward shift of the total market supply, which will usually persist sustainable into the future.

Improved labour productivity can be due to better skilled workers or better managerial efficiency. This can shift the supply curve permanently to the right, increasing production, income, employment and wealth on the macro-level, while the country's general price level declines, making the entire country more competitive. 
The so-called Porter Diamond of Competitiveness (Porter, 1998) emphasise input factors of production, output market conditions, and firm structure, rivalry and management as well as related and supporting firms and services. Modern profit maximisation also requires production management, innovation and marketing at a higher level. In all of this human capital is involved. Utilising modern technology with such proficiency that it leads to new innovations, builds competitiveness, while managerial efficiency has to upgrade processes and apply creative entrepreneurial activity.

When legislation and trade union action push the wage rate up the opposite happens and the industry will move towards selfdestruction, especially when cost structures of firms are distorted in relation to international price structures.

As human capital is involved in all the aspects of production and trade the quality thereof plays a role in all processes. By improving human capital, profit margins and competitiveness increase, making sustain growth possible. This emphasise the need for education and training, especially industry and vocational related training. A large pool of productive workers enable firms to grow as productive labour is available and this will be an important factor when the location of firms is determined (Krugman, 1998). As agglomeration takes place more firms become available in the industrial districts or computer networks and advantages of knowledge and technological spill-overs occur. These spill-overs effects are mainly conveyed by people between different firms which come in contact with each other. Spill-overs effects, education and training as well as experience and learning by doing all enable human capital to accumulate and become more productive. In this way the production function are pushed up continually and diminishing marginal returns may not occur or occur at much higher production levels as predicted by the endogenous growth theory (Cypher \& Dietz, 1997, p. 115). All these aspects of South African industries will be investigated in the empirical section.

\section{Studies on human capital and competitiveness}

There exists an extensive volume of studies related to human capital in the available literature. Mayikana (2002) states that "the future of competition is human", but focuses mainly on human capital management. Very few considered the role of it on the competitiveness of firms or nations and none on its role in the South African Competitive Platform. On the other hand productivity received a lot of attention and several authors consider it to be synonymous, although it only entails a single aspect of competitiveness.

To name a few examples: De Jager (2004) studied the productive use of human capital and Yadavalli (2001) the value of human capital in productivity. Van Zyl (2004) suggested cost-production duality as an instrument to measure labour productivity, as well as a unique microeconomic instrument that expresses productivity in monetary terms (Van Zyl \& Kleynhans, 1995). Mazumdar and Van Seventer (2002) described the application of a simple decomposition model to assess the trade off between employment growth and real wage growth, while Wilson (2003) constructed an Input-Output Model of labour productivity equations of the American economy. Several authors estimated whether productivity is improving (like Mantashe, 2004 \& Lewis, 2002) and ways to enhance productivity (e.g. Sigonyela, 2004). Schoeman (2002) argues that the answer to higher levels of growth and development lies in a balanced approach between government expenditures aimed at increasing investment in human capital, research and development and productivity.

Much is written on the enhancement of labour productivity and managerial efficiency. Falkenberg $(2005$, p. 42), for instance, studied companies as learning organisations.
Pistorius (2004) studied the link between competitiveness and innovation, stressing that human resources are one of the most important components of a national innovation strategy. The role of management is studied by authors like Brooks (2004), while others discuss specific management challenges, like managing knowledge (De Villiers \& Michel, 2004; Redelinghuys, 2001).

Cascio (2005, p. 16) considered the economic benefits of effective human capital management. Others in the similar fields are Wright and Breytenbach (2004) and Horwitz (2005) said "HR can advance competitiveness".

The Institute for Management Development's (IMD) studies strengths and weaknesses according to world competitiveness indices, ranking countries, stressing the importance of marketing a country. Beisiegel (2003) emphasises that productivity improvement will ultimately raise the standard of living of all South Africans as did Van den Berg (2003) who found that a country's standard of living depends on its productivity.

Trostel (2000) investigated micro evidence on human capital as the engine of growth and its relation to endogenous growth. In firm-specific studies Grimbeek (2005, p. 39) studied the business philosophy of Nissan (SA), Schoeman and Roode (2004) the importance of leadership for continuous growth of Clover Industries, while Kaplan (2004) investigated comparative industrial performance in the South Africa's motor and textile industries. Aljuhani (2002) studied labour utilisation and labour productivity of a gold mine in Saudi Arabia, while Fedderke and Pirouz (2002) and Radebe (2002) examined the labour cost and labour productivity in South African mining sectors.

Focussing specifically on competitiveness Siggel (2000 \& 2001) studied industrial price competitiveness in India and Uganda, while Mbaye and Golub (2002) studied unit labour costs, international competitiveness and exports in Senegal. Mulder and De Groot (2004) made an international comparison of labour-productivity performance. De Jong and Soete (2005) made a comparative description of the productivity in Belgian and Dutch manufacturing, Cörvers (2005) considered the impact of human capital on labour productivity in manufacturing sectors of the European Union and GaldonSanchez and Schmitz (2003) studied labour productivity Atlantic iron ore producers; to name a few.

Van Dijk (2003) investigated South African manufacturing performance in international perspective and compared the labour productivity gap with that of the United States. Hooper and Larin (1989) made an international comparison of labour cost in manufacturing and Van Seventer (2002) a decomposition of the source of cost distortion for South African Industry, while Mazumdar and Van Seventer (2004) investigated real wage growth for South African manufacturing, based on price competitiveness.

The above gave a sample of an enormous volume of recent publications on human capital that exists. It also indicated that a study of the role of human capital in the South African industrial competitiveness platform was still not adequately investigated and that is the reason why this study was conducted.

\section{Aim of the study}

The objective of this study was to investigate the role of human capital in the competitive platform of South African industries and to determine the ability of their human capital to address the challenges of modern technology and globalisation.

The following section gives attention to an empirical study that was conducted among South African manufacturers. 


\section{RESEARCH DESIGN}

\section{Research approach}

An empirical investigation of the competitiveness platform of manufacturers was conducted to determine South Africa's ability to address the challenges presented by modern technological development and globalisation. A survey design was utilised to reach the research objectives. The specific design was the cross-sectional design, where a sample is drawn from a population at a particular point in time (Shaughnessy \& Zechmeister, 1997).

\section{Research methodology}

\section{Participants}

From a database of 14000 manufacturing firms 450 firms were randomly selected and a questionnaire was posted to them during 2002. The response was 16,7 per cent, which is regarded as satisfactory for a mail-based survey in Africa. Although the author would prefer to report only on the responding firms of the survey as a case study, most findings correlate with earlier studies like those of the South African Netherlands Programme on Alternative approaches to Development (SANPAD, 1999, 2000), Roberts and Mohamed (2005) and Koch and Ntege (2005) and some generalisation might be in order.

The response to the questionnaire covered a good spread of firms. Most respondents were from small firms $(45,5 \%)$ employing less than 50 employees, while 28,8 per cent were from large firms, employing more than 250 workers. The number of employees ranged between one and 8400 employees. A total of 47,6 per cent of the responding firms have an annual turnover in excess of R10 million, 27 per cent were between one and five million and 15,9 per cent have a turnover of less than a R1 million annually.

Considering the various sub-sectors of manufacturing the largest response of 22,4 per cent was from the sub-sector manufacturing products of basic metals, machinery and office equipment, followed by 20,7 per cent from food processing and beverages, 12,1 per cent by producers of chemicals, chemical products, coke, petroleum products, nuclear fuel, and products from rubber and plastic, 21,1 per cent from textiles, clothing and leather products, and 10,3 per cent came from the sub-sectors of electrical and electronic equipment taken together.

Considering the spatial response from the nine provinces in South Africa; the largest response of 39,6 per cent was from Gauteng, compared to 13,6 from the Eastern Cape, 12,1 from North West and 10,6 per cent from the Free State. From some provinces the response was so small, making generalisation impossible. Some firms were visited in person to complete and collect questionnaires making the response from Gauteng disproportionally higher than the other provinces. Gauteng is, however, the most important centre of manufacturing, producing more than half of South Africa's GDP.

\section{Measuring instrument}

A questionnaire was designed with the assistance of the Industrial Development Corporation (IDC), in which most questions expected respondents to rate aspects of competitiveness on a five-point scale between "poor" and "excellent". In compiling the questionnaire the Porter's Competitiveness Diamond was taken as the basis, taking into consideration input factors, demand conditions, firm strategy, structure and rivalry, and related and supporting firms, which represents the industrial competitive platform. The questionnaire was extended to include questions measuring specific aspects, like location and expectations. In calculating indices, the methodology was similar in principal to that applied by the International Institute for Management Development (IMD) in calculating the annual World Competitiveness Indices.

\section{Data Analysis}

The data was analysed in co-operation with the Statistical Consultation Service of the North-West University. The data were mostly descriptive, although correlations and regression analysis were estimated where applicable.

Affirmative factor analysis was done and the significantly high values of Cronbach-Alpha coefficients that were obtained indicated that the questionnaire was a reliable measuring instrument to measure the proposed objectives. Table 1 indicates some of the most important Cronbach-Alpha coefficients of the various groups of questions. To be reliable Cronbach-Alpha coefficients should exceed 0,5 and Table 1 indicates that all values were satisfactory, most exceeding 0,8 (Kleynhans, 2003a, p. 242). The high Cronbach-Alpha values and the consistency of the responses to the items in the survey suggest that respondents completed the questionnaire with great care and a high degree of accuracy.

TABLE 1

Cronbach-Alpha coefficients

\begin{tabular}{lc}
\hline Question Groups & Coefficients \\
\hline Human Capital & 0,855 \\
Resources & 0,892 \\
Demand Conditions & 0,815 \\
Related \& Supporting Indust. \& Instit. & 0,878 \\
Firm Strategy, Structure \& Rivalry & 0,873 \\
Technology \& Innovation & 0,914 \\
Quality \& Environment & 0,801 \\
Perspective \& Expectations: Current & 0,868 \\
Perspective \& Expectations: Future & 0,789 \\
Shortages: Current Quarter & 0,917 \\
Shortages: Future & 0,863 \\
\hline
\end{tabular}

\section{RESULTS}

\section{General Findings}

The most important findings regarding the competitive platform of South Africa are represented in Figure 1. Most questions of the questionnaire expected respondents to rate their response on a five-point scale where 5 is excellent, 4 is good, 3 fair, 2 poor and 1 very bad. Although South Africa is a less developed country, all categories were on average rated about fair, but none of the main constructs of the questionnaire was rated good or excellent. Human resources rated much higher than expected. The survey affirmed the perception that the country's human capital is between "fair" and "poor", especially low on productivity, motivation and work ethics. The country's managerial shortage is a stylised fact, but the survey also highlighted a shortage of artisans, which merits attention (Kleynhans, 2003b, p. 16). The supply of unskilled labour is as can be expected fairly well, and that of technical and managerial staff fair. Very few responding firms rated the availability of any component of labour as very poor. Vocational and industry related training facilities are also insufficient.

The findings revealed that human capital is not the worst element of South Africa's competitive platform. As illustrated in Figure 1 most respondents perceive the human capital base in South Africa to be fair. None of the main constructs were seen as poor but there is much room for improvement, as none were regarded as good or excellent ether. "Other recourses", "technology" and "quality" are stronger elements of the competitiveness platform in South Africa, as is "strategy, structure and rivalry", and this includes managerial performance, which is also part of human capital. 


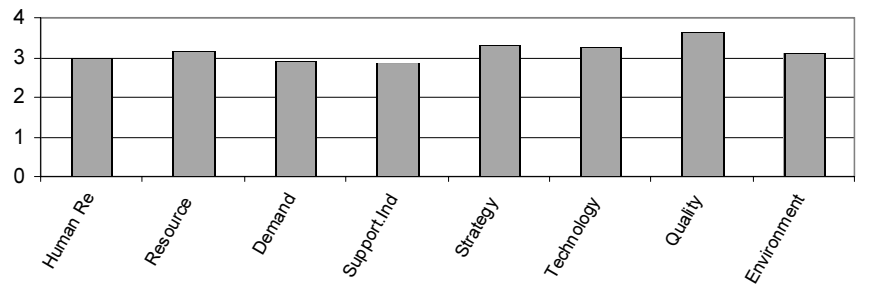

Figure 1: Strengths and opportunities

It is further indicated in Figure 1 that the country's technological base is rated between "fair" and "good", as is management strategy and quality, where human capital also has a role to play. In some industries, like electronics, a poor technological platform is still hampering competitiveness though and the technological base was not rated as good in any industry. The provision of support services, like cold storage and harbour facilities, for example, is inefficient and where they do exist, it is not utilised.

All firms have a very poor perception of the government and civil service, rating them between poor and very bad. The worst rating was that of civil servants that is regarded as poor with a standard deviation of only 0,9 on a five-point scale and none of the respondents viewed them as being very efficient. They are regarded as inefficient and non co-operative. Competitivity is also retarded due to a lack of government assistance, information, aid and incentives, political and policy instability. This is a matter that merits serious attention from the government. As usual respondents are unhappy about high costs, taxes and interest rates. There are sometimes shortages of raw materials but it is not serious. Finally poor market demand restricts the competitiveness and growth of manufacturers.

Most respondents regard wage rates, unit labour costs and workplace regulations to be fair, while their perception of productivity is poor, impeding the competitiveness of firms. Respondents do not expect the average working hours per factory worker, the average total cost per unit of production or the average labour cost per unit of production to change in the near future.

Considering the four corners of the Porter Diamond, competitiveness of South African manufacturers the quality of human capital and the civil service needs lots of attention. It was found that the availability and quality of most input factors were found satisfactory. Some capital goods are imported at very high prices and a shortage of skilled labour and managers are sometimes a problem, though not a serious obstacle and shortages do not hamper production. The all over rating of human resources was, however, poor, pushing cost curves up.

Considering the measures of globalisation the availability and quality of skilled labour is low and not enough is being done to improve human capital. It does not seem that South African firms are adequately equipped to compete in the new economy yet. Although the level of technology is fair, the supporting labour is lacking and unproductive. As most workers lack the necessary skills modern equipment cannot be optimally utilised in many instances.

\section{Government Assistance and Legislative Issues}

Some manufacturers suggested that the government should support manufacturing much more, especially through direct measures. There is a need for more incentives to local manufacturing. Some asked for subsidies on transport and wages, like those that existed in the past. More should be done to promote exports, training and manpower development. Attention should also be given to local value added services such as consultants, design, building, education and maintenance.
Some respondents expressed concern against the growing power of trade unions. Some manufacturers regard the current labour laws as being "draconian", which together with affirmative equity laws are onerous and hostile towards industrial development and need to be addressed. Black empowerment programs are seen as restricting industrial expansion and investment and some manufacturers suggested that it should be suspended. Labour laws make it difficult for small businesses to control their own businesses and remain competitive. Healthier labour relations with manufacturers and deregulation of employment practices are requested. Current labour legislation is not seen as an incentive to employ more people, but increases unemployment (this perception is also expressed in current literature; see e.g. Maziya, 2001:211).

Trade union demands and other rising costs present other countries like China with opportunities to compete favourable in the South African market, especially with labour intensive business. Local manufacturers therefore plead for a surcharge on import based on the difference in variable costs such as labour, energy and transport. A national drive towards awareness of and commitment to productivity to increase international competitiveness was suggested including training courses, advertising, propaganda and a national productivity day.

It is suggested that the skills development levy should be cancelled as firms can effectively only claim fifteen per cent of the levy back. Respondents also suggested that annual wage increases should be linked to the geographical area.

\section{Education and Training}

The educational level of labour in general should be improved. The low levels of literacy restrict the trainability of most unskilled workers. People should also be trained to acquire quality skills. Vocational and industry related training facilities are insufficient and there are a serious shortage prospects for artisan training. Development of workers skills should receive more attention and the authorities may consider the subcontracting of private developers. Continued investment, development and upgrading of human capital are crucial to obtain and expand competitiveness. On average, respondents view the vocational and industry related training facilities in South Africa to be poor.

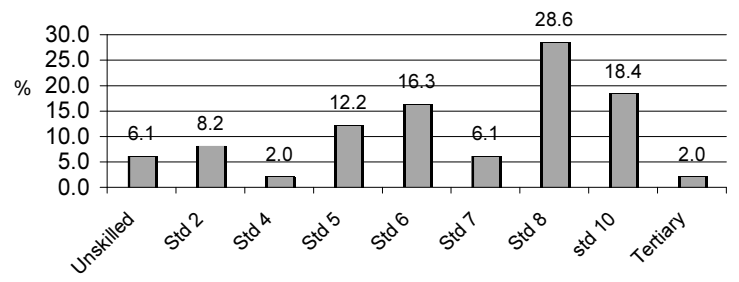

Figure 2: Education of unskilled labourers

The educational level of unskilled labour of the survey is shown in Figure 2. The highest level is on average about ten years of school education and only 6,1 per cent of the firms employ mostly workers that are totally illiterate. Nearly half (49\%) of the unskilled workers have ten years or more, which are far higher than would have been expected.

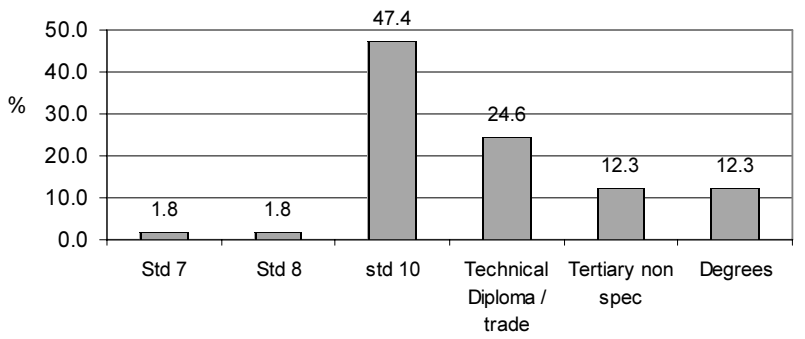

Figure 3: Qualifications of skilled personal 
On the other hand the average level of education among skilled personal is not very high. Figure 3 shows the average level of education among skilled labourers in the firms studied. Almost half $(47,4 \%)$ of the workers in this category have only matric and about a quarter $(24,6 \%)$ has technical diplomas or are skilled artisans. Twelve per cent have degrees and another 12,3 per cent tertiary training of some sort although those respondents did not specify.

\section{Reasons for Absenteeism}

Main reasons why employees are absent from work is illness. The kind of illness was unfortunately not specified. Figure 4 shows the main reasons for absence according to respondents. The largest reason following unspecified illness is problems with transport and HIV/AIDS. Many of the other reported illnesses could also be AIDS related. Influenza and TB respectively were both given by 9,6 per cent of the manufacturers as major reasons for absentees. Respondents viewed low work ethics as an important factor causing absentees, 9,6 per cent saw workers being unmotivated as a major reason for absentees and another 11 per cent explicitly named laziness and 1,4 per cent disloyalty as major reasons. On the specific questions on work ethics and productivity, most employers rated it as being poor, although some manufacturers also have excellent motivated and productive workers. This should be addressed as workers that do not feel satisfied in their working conditions are neither committed nor productive, pushing marginal cost curves in the wrong direction. Manufacturing-labour is, however, newer rated as inefficient as civil servants. Although family responsibilities was only seen as a major problem by about 10 per cent of the respondents, tradition was only in 4,1 per cent of the cases a major cause of absentees and trade action was only in 1,4 per cent of the firms a major reason for absentees.

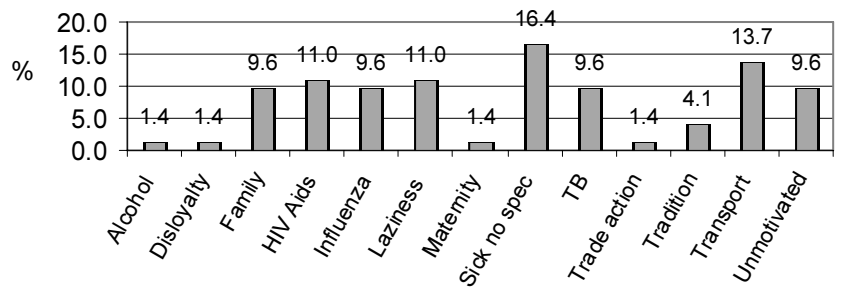

Figure 4: Absent from work

\section{Social Infrastructure}

The next aspect investigated (not shown on the graph) was social infrastructure near their premises, which was rated by respondents on average, to be fair but they rated the availability of health services to be poor. This probably implies that they feel satisfied with their social infrastructure but view the availability of medical assistance to their employees to be insufficient. The availability of schools, colleges, universities and other industrial training facilities near the premises of manufacturers is a problem and leads to problems obtaining skilled labour. They are satisfied with their managerial skills and practices, but feel that the proximity of professional services is in most cases inadequate.

\section{Locational Factors}

The New Economic Geography emphasises a pool of skilled, intermediate inputs, knowledge and technological spill-overs as the most important factors of industrial location. Regarding locational aspects of their premises, respondents on average rated both traditional factors of location and modern factors to be poor. Neither factors like proximity to markets, low taxes, the availability of land, financial and trucking services, nor modern factors like the proximity of support services, the availability of skilled labour and industrial training facilities are seen as enhancing their efficiency and competitiveness due to their location.

\section{Management}

Respondents rate the availability of managerial staff as being poor but rate the abilities of management to be on average higher than that of other labour and contributing towards higher competitivity. Management is competent and has goods contacts leading to strategic positioning in the market competing successfully with rivals. The most important aspect hampering their activities is shortages of raw material, followed by shortages of skilled labour, machinery and equipment, maintenance and supporting industries.

Co-operation with competitors was seen to be poor but all other factors relating to firm strategy, structure, and rivalry in the South African economy were perceived by the respondents to be fair to good. As businesses usually try to please their customers, respondents saw co-operation with clients to be the strongest factor. Other factors that were seen to be between fair and good were co-operation with suppliers, managerial practice, and managerial skills in the integration and innovation of business activities, employee performance incentives and business contacts. The ability of firms to enter foreign markets, their growth in exports, and profits were also seen as being satisfactory.

\section{Competitiveness and the Size of Firms}

Figure 5 illustrates that all aspects of competitiveness grew with firm size, except human resources. Smaller firms are more labour intensive and this might be the reason why the largest companies are not so competitive when human capital is considered. Demand for skilled and specialised labour increases as firm size increases and this might also be a reason why respondents of the largest firms rate the quality of their labour input as less efficient. Larger companies can achieve scale economies, as they are more efficient and more competitive, utilising higher technology.

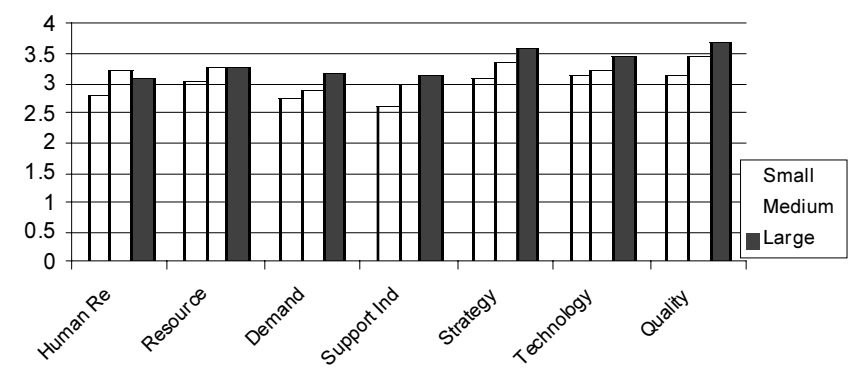

Figure 5: Competitiveness and firm size

The factors of which large companies are experiencing a slight shortage of are skilled labour, managerial staff, raw materials, machinery and equipment and technology and knowledge support services. The only factors that large companies expect to decline in future are electricity and the availability of factory workers, including skilled labour, probably due to the effect of HIV/AIDS.

Small firms rate all aspects of their human capital to be poor. The only aspects that are satisfactory are the availability of unskilled workers and workplace regulations. The worst aspects are the efficiency of civil servants, which none rated as excellent, followed by a shortage of managerial staff and artisans and industry related training facilities. Medium sized firms also experienced problems with the inefficient civil service and inadequate training facilities, but also with the work ethics of the workforce that are unmotivated, neglected and not conscientious. The respondents of medium sized firms rated all other factors relating to human capital as fair. Large companies also found inefficient civil servants to be their greatest obstacle 
to competitiveness when considering human capital, followed by high unit costs per worker. Other factors were all satisfactory and the best factor was the availability of unskilled labour.

TABLE 2

OVERHEAD COST PER LABOURER: FirM SIZE

\begin{tabular}{lc}
\hline Large & 37757 \\
Medium & 116896 \\
Small & 128837 \\
Total Sample & 109316 \\
\hline
\end{tabular}

All firms find labour cost to be a fair obstacle, to small firms this is a little bit higher, but there are no significant differences between firms of different sizes. The overhead per worker in smaller firms are higher and declines with firm size. This might be because larger firms have more employees. This might suggest that smaller firms are not as productive; it also correlates with the productivity indices of Table 4 , which indicates that productivity rises with firm size. It is, however, doubted that the overhead cost per labourer could be interpreted as a measure of productivity as fewer people have to handle more overheads in smaller firms.

\section{DISCUSSION}

The role of human capital in the competitive platform of South African manufacturing industries is investigated in this paper. Attention was first give to a theoretical background to the role of human capital in enhancing competitiveness, followed by a review of the current literature. Then attention was given to a survey conducted among South African manufacturing industries.

This paper reported on an empirical study conducted among manufacturers, which investigated human capital's ability to answer to the challenges of modern technology and globalisation. Attention was given to the competitive strengths and investment opportunities, including the quality and availability of human resources, labour cost, level of education and skills, vocational and industry related training facility, work ethic of labour force, productivity of labour force, workplace regulations, as well as efficiency of the civil service, including productivity and competitiveness indexes. Other aspects like social infrastructure near their premises and health services were also included in the study, as well as the situation in the various provinces, firm-sizes and sub-sectors of manufacturing were compared.

The study found that the level of human capital in South African industries much higher than generally perceived and not the worst element of South Africa's competitive platform. The findings also indicated challenges, however, like absentees due to AIDS and other specific factors, a shortage of artisans and proficiency towards modern technology and innovation. The following section gives some recommendations following the results of this study.

\section{RECOMMENDATIONS}

The study indicated a negative perception of the civil service and government by manufacturers. Government should provide in service training in an effort to transform the civil service into a more efficient and consumer friendly service. Services should be improved and benefits to workers and industry should be obtained much easier cutting unnecessary bureaucratic procedure.
To some extend the criticism against government and the civil service is unfounded, but the existence of such perceptions indicates that government should provide much more information to workers and industry. From the existing perceptions it can be presumed that government's communication channels are insufficient. Improving effective communication and to some extend positive propaganda might be to everyone's advantage.

To answer the challenges of globalisation, modern technology and economic growth industries need well trained personnel. Since 1994 the training system of artisans in the country has collapsed. Government should, in co-operation with technical colleges and large industries, like mining, construct a new system of artisan and other vocational and industrial training, which would supply in the needed demand for trained personnel, quality labour in the shortest possible duration of training. Companies need more incentives to provide training of their people. Other adult educational training schemes, like reading classes and courses to complete matric and higher education should also be promoted.

Companies should make an effort to motivate their workers in such a way that they would feel part of the company. The large number so-called lazy and unmotivated workers are an indication that people do not associate with their vacations in a way that can lead to higher productivity and industrial growth. Expecting more responsibility, empowerment, company shares as part of their remuneration and various training programmes might be of advantage in this regard.

The study also revealed much detail that should be followed up, like the fact that there is a need for cold storage facilities, and specific artisans, like toolmakers in the plastics industry and carpenter in the wining industry.

The role of human capital in the competitive platform of South African industries should be further investigated to enable generalisation of the findings and determine whether trends persist over time. Further research, especially with larger samples, can enable comparison of firms in the various sub-sectors of manufacturing, like food processing, basic metal products and textiles, as well as the various provinces. The study should be conducted annually and on a larger scale, when funds permit, to determine whether structural changes occurred. This will yield more reliable data and provide policymakers, industries and researchers with instruments to design better industrial development programmes and policies, especially in a spatial context.

This study estimated competitive indices for provinces and its various sub-divisions, like management, resources, technology, and these findings correlated well with productivity indices, as is illustrated in tables 3 and 4 . The same apply to sub-sectors of manufacturing, and different firm-sizes; but as the response rate was too small to differentiate the sample into such small units, it can at this stage only be regarded as an academic exercise. The instruments were, however, developed in this study and can now be implemented in further investigations.

The competitiveness indexes calculated for various provinces is similar to the World Competitiveness Index of the International Institute for Management Development and tested to determine whether the groups form a reliable instrument and whether it is statistically significant (IMD, 2001, pp. 516-7). The values of Cronbach alpha coefficients calculated were again averaging between 0,7 and 0,9 indicating that the groups of questions probably serve as a reliable measuring instrument. Among the manufacturers investigated spatial differences in human capital were found among the various provinces as illustrated in Table 3 . Very little differences exist, however, between human capital in the 
TABLE 3

COMPETITVE INDICES OF THE PROVINCES OF SOUTH AFRICA

\begin{tabular}{|c|c|c|c|c|c|c|c|c|c|c|}
\hline Sub-Categories & Ranking & $\begin{array}{c}\text { Local } \\
\text { Economy }\end{array}$ & $\begin{array}{l}\text { International- } \\
\text { isation }\end{array}$ & $\begin{array}{l}\text { Govern- } \\
\text { ment }\end{array}$ & Finance & $\begin{array}{c}\text { Infra- } \\
\text { structure }\end{array}$ & $\begin{array}{l}\text { Manage- } \\
\text { ment }\end{array}$ & $\begin{array}{c}\text { Science \& } \\
\text { Technology }\end{array}$ & People & Total \\
\hline KwaZulu/Natal & 1 & 0,872 & 0,623 & 0,893 & 0,744 & 1,584 & 0,921 & 0,987 & 1,592 & 1,032 \\
\hline North West & 2 & 1,301 & 1,134 & 1,184 & 0,64 & 0,713 & 1,029 & 0,759 & 0,217 & 0,965 \\
\hline Mpumalanga & 3 & 0,971 & 1,368 & 0,484 & 0,591 & 0,22 & 0,674 & 0,918 & $-0,567$ & 0,687 \\
\hline Eastern Cape & 4 & 0,306 & 0,55 & 0,252 & 0,653 & 0,923 & 0,206 & 0,041 & 0,408 & 0,473 \\
\hline Gauteng & 5 & 0,478 & 0,085 & 0,574 & 0,145 & 0,347 & 0,336 & 0,531 & 0,867 & 0,401 \\
\hline Northern Cape & 6 & $-1,031$ & $-0,925$ & $-0,922$ & $-0,572$ & $-1,125$ & $-0,965$ & $-1,434$ & $-0,526$ & $-0,999$ \\
\hline Free State & 7 & $-0,673$ & $-0,483$ & $-0,177$ & 0,471 & $-0,498$ & $-0,017$ & $-0,123$ & 0,572 & $-0,113$ \\
\hline Western Cape & 8 & $-0,727$ & $-0,796$ & $-0,229$ & $-0,308$ & $-0,85$ & $-0,054$ & $-0,319$ & $-0,898$ & $-0,465$ \\
\hline Limpopo & 9 & $-1,496$ & $-1,557$ & $-2,059$ & $-2,365$ & $-1,314$ & $-2,133$ & $-1,728$ & $-1,664$ & $-1,971$ \\
\hline
\end{tabular}

various sub-sectors of manufacturing and their influence on competitiveness.

Literature of the IMD on their calculation of the World Competitive Indices is not very clear and it was decided to base the calculations on their methodology but alter it to suit the need of this study. Basically the method calculates a group average and compares, firms or groups of firms in provinces or industries using their standardised standard deviation from the average. A higher value implies higher competitiveness, while a positive value implies competitiveness above the average and a negative value indicates a level of competitiveness that is below average.

These indices can suggest an agenda for development. Finance, management and infrastructure deserves attention in Gauteng, for instance, while the local economy, internationalisation and people need attention in North West and the Western Cape should focus on the local economy, business efficiency, internationalisation, infrastructure and human capital. Limpopo, Western Cape and the Northern Cape have the lowest productivity indices and attention should be given to the development of human capital, science and technology to enhance efficiency and productivity.

TABLE 4

Productivity indeX

\begin{tabular}{|c|c|c|c|c|c|}
\hline \multicolumn{2}{|c|}{ Provincial Indices } & \multicolumn{2}{|l|}{ Sub-Sector Indices } & $\begin{array}{l}\text { Firm } \\
\text { Indices }\end{array}$ & Size \\
\hline KwaZulu Natal & 0,802 & Fond & $-0,199$ & Large & 0,687 \\
\hline North West & 0,966 & Textiles & $-0,563$ & Medium & 0,119 \\
\hline Mpumalanga & 0,604 & Paper \& Wood & $-1,378$ & Small & $-1,054$ \\
\hline Eastern Cape & $-0,208$ & Chemicals & 0,771 & & \\
\hline Gauteng & 0,383 & Non-Metal Mine & 1,561 & & \\
\hline Northern Cape & $-0,434$ & Basic Metal Prod & 0,995 & & \\
\hline Free State & 0,731 & Electrical & $-1,897$ & & \\
\hline Western Cape & $-0,681$ & Electronics & 0,178 & & \\
\hline Limpopo & $-2,164$ & Transport & 0,1778 & & \\
\hline & & Furniture & 0,1778 & & \\
\hline
\end{tabular}

Cronbach Alpha Coefficient: 0,741
An alarming aspect was the low level of technological proficiency, expertise and innovation in the science- and technology-based industries like chemicals and electronics. If South Africa is to survive in the new economy its level of technological expertise, capabilities and capacity will have to be improved considerably.

Much research is conducted on SMMEs, but larger firms are neglected and deserves further investigated. The synergy between small, medium and large firms also deserves attention. When considering the theory of production it was shown that the most important aspect in enhancing industrial competitiveness was in addressing the cost structures of firms. An important extension to this study will be the calculation of cost competitiveness, like the studies done by Siggel (2000 \& 2001), Van Seventer (2002) and Van Seventer and Molate (2002). These studies could, however, be contradictory and focus only on productivity as comparative unit cost ratios are calculated as the ratio between total costs and the value added (Siggel, 2000, p. 13). A problem when determining cost competitiveness is the availability of detailed data and the estimation of shadow prices. Further study of the role of human capital in the competitive platform of South African industries would contribute towards everyone's welfare and prosperity.

\section{AUTHOR'S NOTE}

This paper was delivered at the 2005 Biannual Conference of the Economic Society of South Africa. Durban and recommendations were incorporated.

\section{REFERENCES}

Aljuhani, M.S.M. (2002). Labour's utilization and labour's productivity of a gold mine in Saudi Arabia. Journal of the South African Institute of Mining and Metallurgy, 102, 307-309.

Beisiegel, H. (2003). Productivity and beyond. Productivity, 8-9.

Brooks, M. (2004). Project management: opportunity for senior managers. Management Today, 20, 49.

Cascio, W. (2005). Effective human capital management: huge benefits. Management Today, 21, 16-18.

Cörvers. F. (2005). The impact of human capital on labour productivity in manufacturing sectors of the European Union. Research Memoranda from Maastricht no 1. Researchcentrum voor Onderwijs en Arbeidsmarkt

Cypher, J.M. \& Dietz, J.L. (1997). The process of economic development. London: Routledge. 
De Jager, J. (2004). The productive use of human capital. Productivity SA, 30, 16-17.

De Jong, H. \& Soete, A. (2005). Comparative levels of labour productivity and labour costs in manufacturing in Belgium and the Netherlands, 1921-1990. CCSO Working Papers from University of Groningen, no 199904, CCSO Centre for Economic Research.

De Villiers, A. \& Michel, P. (2004). Knowledge management: the critical mass lies below the surface. Management Today, 20, 22-25.

Falkenberg, R. (2005). The learning organisation: the evolving reality. Management Today, 21, 42-43.

Fedderke, J. \& Pirouz, F. (2002). The role of mining in the South African economy. South African Journal of Economic and Management Sciences, 5, 1-34.

Galdon-Sanchez, J.E. \& Schmitz, J. (2003). Competitive pressure and labor productivity: world iron ore markets in the 1980s. Quarterly Review. Federal Reserve Bank of Minneapolis.

Grimbeek, H. (2005). Human resources: strategic human capital management required. Management Today, 20, 39-40.

Hooper. P \& Larin, K.A. (1989). International comparison of labour cost in manufacturing. Review of Income and Wealth, $35,335-355$.

Horwitz, F. (2005). HR can advance competitiveness. Executive Business Brief, 10, 50-52.

IMD. (1998 - 2002). World competitiveness yearbook. Lausanne: International Institute for Management Development.

Kleynhans, E.P.J. (2003a.) The competitive platform for industrial development in South Africa. Ph.D.- thesis. Potchefstroom: Potchefstroom University.

Kleynhans, E.P.J. (2003b.) The effect of globalisation on industrial development: The South African Experience. Paper delivered at the Conference on Clusters, Industrial Districts and Firms. University of Modena and Reggio Emelia. Modena, Italy. 12 Sept.

Krugman, P. (1998). What's new about the new economic geography? Oxford Review of Economic Policy, 14, 7-17.

Koch, S.F. \& Ntege, S.S. (2005). HIV/AIDS and labour regulation: The impact of information asymmetries on labour marker outcomes. Paper delivered at the Biannual Conference of the Economic Society of South Africa. Durban. 7-9 Sept. 2005.

Lewis, N. (2002). South Africa becomes more competitive. Productivity, 6-9.

Mayikana, M. (2002). The future of competition is human. Management Today, 18, 26-27.

Mazumdar, D. \& Van Seventer, D. (2002). A decomposition of growth of the real wage rate for South Africa, 1970-2000. South African Journal of Economics, 70, 1076-1102.

Mbaye, A.A. \& Golub, S. (2002). Unit Labour Costs, International Competitiveness, and Exports: The Case of Senegal. Journal of African Economies, 11, 219-248.

Mulder, P. \& De Groot, H.L.F. (2004). International Comparisons of Sectoral Energy- and Labour-Productivity Performance: Stylised Facts and Decomposition of Trends. CPB Netherlands Bureau for Economic Policy Analysis.

Oulton, N. (2003). Competition and the dispersion of labour productivity amongst companies. Working Papers from National Institute of Economic and Social Research.

Pistorius, C. (2004). Competitiveness and innovation. Elektron, 21,3 .

Porter, M.E. (1998). The competitive advantage of nations; with a new introduction. New York: Palgrave.

Radebe, B. (2002). Productivity in the mining industry. Productivity, 29-31.

Redelinghuys, W. (2001). Intellectual capital management critical for international business success. Management Today, 17, 10-11.
Roberts, S. \& Mohamed, L. (2005). Analysis of the Technological Challenge Faced by the Plastics Sector and its Dynamism. Paper delivered at a workshop on The Role of Networks, Relationships, Industrial Clusters and Innovation Systems in Africa. Johannesburg.

SANPAD see SOUTH AFRICA - NETHERLANDS RESEARCH PROGRAMME ON ALTERNATIVES IN DEVELOPMENT

Schoeman, A. \& Roode, M. (2004). Leadership: essential for continuous growth. Management Today, 20, 42-43.

Schoeman, N. (2002). Economic growth and development constraints in SA. Productivity, 22-23.

Shaughnessy, J.J. \& Zechmeister, E.B. (1997). Research methods in psychology (4th ed.). New York: McGraw-Hill.

Siggel, E. (2001). India's trade policy reforms and industry competitiveness in the 1980s. World Economy, 159-183.

Siggel, E. (2000). Uganda's policy reforms, industry competitiveness and regional integration: A comparison with Kenya. African Economic Policy. Discussion paper 24. Washington: United States Agency for International Development: Bureau for Africa.

Sigonyela, M. (2004). How can we enhance productivity through share incentive schemes. Productivity, 10-11.

SOUTH AFRICA - NETHERLANDS RESEARCH PROGRAMME ON ALTERNATIVES IN DEVELOPMENT. (2000). Annual report 2000: The manufacturing sector in North West Province. Prepared by Naudé, W.A; Serumaga-Zake, P. \& Oostendorp, R. Potchefstroom: Potchefstroom University.

SOUTH AFRICA - NETHERLANDS RESEARCH PROGRAMME ON ALTERNATIVES IN DEVELOPMENT. (1999). First annual report 1999: Manufacturing survey: North West Province of South Africa. Prepared by Naudé, W.A; Oostendorp, R; Anand, V.K. \&. Serumaga-Zake, P. Potchefstroom: Potchefstroom University.

Todaro, M.P. \& Smith, S.C. (2003). Economic development. Boston: Addison Wesley.

Trostel P.A. (2000). Micro Evidence on human capital as the engine of growth. The Warwick Economics Research Paper Series (TWERPS). Department of Economics, University of Warwick.

Valadkhani, A. (2003). An Empirical Analysis of Australian Labour Productivity. Australian Economic Papers, 42, 273-291.

Van den Berg, L. (2003). A country's standard of living depends on its productivity. Productivity, 20-21.

Van Dijk, M. (2003). South African manufacturing performance in international perspective, 1970-1999. South African Journal of Economics, 71, 119-142.

Van Seventer, D.E. (2002). A decomposition of the source of cost distortion for South African Industry. Paper presented at the Competitiveness workshop of the (TIPS). Johanesburg.

Van Seventer, D.E. \& Molate, C. (2002). Export competitiveness, a trade performance index for South Africa. Paper compiled for the TIPS conference. Department of Trade and Industry.

Van Zyl, G. (2004). The cost-production duality approach to the measurement of labour productivity: a dynamic tool for effective human resource management. SA Journal of Human Resource Management, 2, 50-53.

Van Zyl, G. \& Kleynhans, E.P.J. (1995). A Cobb-Douglas estimation of labour productivity in the South African motor vehicle industry. SA Journal of Industrial Psychology, 21, 6-9.

Wilson, D. (2003). Embodying embodiment in a structural, macroeconomic Input-Output Model. Economic Systems Research, 15, 371-398.

Wright, F. \& Breytenbach, K. (2004). You mismanage human resources, you strangle your business. People Dynamics, 22, 26-27.

Yadavalli, L. (2001). Value of human capital in productivity. Productivity, 6-10. 


\section{REVIEW PANEL EDITION 4.3}

Mr Giel Bekker (M. Eng)

Prof WJ Coetsee

Prof J Degadt

Dr Derrik de Jongh

Prof Piet de la Rey

Dr Y du Plessis

Prof LTB Jackson

Prof J Kroon

Mr Ivan Latti

Prof S Rothmann

Mr Michael Routledge (Industrial Psychologist)

Prof AMG Schreuder

Prof AJ Smith

Dr M Ungerer

Prof JS Uys

Dr M Venter (Economist)
University of Pretoria

University of Johannesburg

Katholieke Universiteit, Brussels, Belgium

UNISA

Emeritus Professor - University of Pretoria

University of Pretoria

North-West University

North-West University

HR Practitioner

North-West University

Rhodes University

UNISA

University of Pretoria

ABSA

University of Johannesburg

Private Practitioner 